\title{
Unusual Causes of Cushing's Syndrome
}

\begin{abstract}
Although in the majority of the patients with Cushing's syndrome (CS), hypercortisolism is due to ACTH hypersecretion by a pituitary tumour or to ectopic ACTH secretion from an extrapituitary neoplastic lesion or to autonomous cortisol secretion by an adrenal tumour, in occasional patients a much rarer entity may be the cause of the syndrome. Herein, we attempted to summarise and categorise these unusual causes according to their presumed aetiology. To this end, we performed a comprehensive computer-based search for unusual or rare causes of CS. The following unusual forms of CS were identified: (i) ACTH hyperesecretion due to ectopic corticotroph adenomas in the parasellar region or the neurohypophysis, or as part of double adenomas, or gangliocytomas; (ii) ACTH hypersecretion due to ectopic $\mathrm{CRH}$ or $\mathrm{CRH}$-like peptide secretion by various neoplasms; (iii) ACTH-independent cortisol hypersecretion from ectopic or bilateral adrenal adenomas; (iv) glucocorticoid hypersensitivity; (v) iatrogenic, due to megestrol administration or to ritonavir and fluticasone co-administration. Such unusual presentations of CS illustrate why Cushing's syndrome represents one of the most puzzling endocrine syndromes. (Arq Bras Endocrinol Metab 2007;51/8:1245-1252)
\end{abstract}

Keywords: Cushing's syndrome; Ectopic adenomas; Gangliocytomas; Glucocorticoid hypersensitivity; Megestrol

\section{RESUMO}

\section{Causas Incomuns da Síndrome de Cushing.}

Embora na maioria dos pacientes com síndrome de Cushing (SC), o hipercortisolismo se deva à hipersecreção de ACTH resultante de um tumor hipofisário ou de uma fonte ectópica de ACTH por uma lesão neoplásica extra-hipofisária, ou ainda pela secreção autônoma de cortisol por um tumor adrenal, ocasionalmente uma entidade muito mais rara pode ser a causa da síndrome. Nesta revisão, tentaremos sumarizar e categorizar essas causas incomuns de acordo com sua pressuposta etiologia. Para isso, fizemos uma ampla pesquisa por computador em busca dessas causas raras ou não usuais de SC. As seguintes formas não usuais de SC foram identificadas: (i) hipersecreção de ACTH devida a adenomas corticotróficos ectópicos na região parasselar ou na neurohipófise, ou como parte de adenomas duplos, ou gangliocitomas; (ii) hipersecreção de $\mathrm{ACTH}$ devida à secreção ectópica de $\mathrm{CRH}$ ou peptídeo CRH-símile por várias neoplasias; (iii) hipersecreção de cortisol ACTHindependente por adenomas adrenais ectópicos ou bilaterais; (iv) hipersensibilidade aos glicocorticóides; (v) iatrogênica, devida à administração de megestrol ou à co-administração de ritonavir e fluticasona. Essas apresentações incomuns da SC ilustram por que essa síndrome é considerada uma das mais desafiadoras da endocrinologia. (Arq Bras Endocrinol Metab 2007;51/8:1245-1252)

Descritores: Síndrome de Cushing; Adenomas ectópicos; Gangliocitomas; Hipersensibilidade aos glicocorticóides; Megestrol

\section{revisão}

\section{DIMITRA VASSILIADI \\ STYLIANOS TSAGARAKIS}

Department of Endocrinology, Division of Medical Sciences, Institute of Biomedical Research, University of Birmingham, B15 2TT Birmingham, UK (DV), and Department of Endocrinology, Athens' Polyclinic, 10552 Athens, Greece (ST).

Recebido em 07/08/07

Aceito em 15/08/07 
$\mathrm{E}$ NDOGENOUS CUSHING's SYNDROME (CS) is a rare syndrome with an estimated annual incidence of 0.1 to 1.0 new cases per 100,000. The ACTH-dependent variety of the syndrome is either due to ACTH hypersecretion from pituitary corticotroph adenomas (Cushing's disease) and represents the vast majority of cases $(70 \%)$ or to ectopic ACTH secretion from various tumour types. The ACTH-independent forms of Cushing's syndrome include adrenal adenomas, carcinomas, and two rare forms of bilateral adrenal pathology, namely ACTH-independent macronodular adrenal hyperplasia (AIMAH) and primary pigmented (micro)nodular adrenal disease (PPNAD). Although the above aetiologies are those usually mentioned in endocrinology textbooks as well as in publications dealing with the differential diagnosis of Cushing's syndrome, some unusual causes described either as individual cases or in small cohorts of patients are usually overlooked. Herein, we attempt to summarise and categorise these cases according to their presumed aetiology. We performed a comprehensive computerbased search for unusual or rare causes of Cushing's syndrome and a search of references in the identified reports. We have excluded unusual but well characterised causes, such as AIMAH, PPNAD, and the ectopic ACTH syndrome, since these forms will be described in detail in respective articles of this volume. We have grouped these reports according to their presumed aetiology although in some cases the underlying mechanism was only speculative.

\section{UNUSUAL CAUSES OF ACTH-DEPENDENT CUSHING'S SYNDROME (table 1)}

\section{Ectopic corticotroph adenomas}

By definition, ectopic adenomas are histologically confirmed corticotroph adenomas located outside the sella turcica and not in direct connection with the intrasellar pituitary tissue. Pituitary gland is normal or, in some cases, an empty sella is found. Ectopic corticotroph adenomas represent a rare finding and most of them are located in the sphenoid sinus and the suprasellar region but also in the cavernous sinus and the parasellar region. So far only 31 cases of ACTH-producing ectopic pituitary adenomas have been reported (1). However, their true incidence may be higher than reflected by the scarce case reports. It has been suggested that at least some of the patients with presumed Cushing's disease in whom hypercortisolism persisted even after total hypophysectomy may indeed had harboured extrapituitary parasellar adenomas that remained undiagnosed because remission was achieved by parasellar irradiation $(2,3)$, bilateral adrenalectomy (4), or the adenoma was removed accidentally (5). Interestingly, five cases have been reported in which an extrapituitary parasellar corticotroph adenoma progressed to Nelson's syndrome after bilateral adrenalectomy (5).

As to their origin it has been suggested that ectopic corticotroph adenomas develop from pituitary cells deposited along the route of the embryogenic development of the anterior pituitary, namely the Rathke's pouch (5). The finding in several cases of an empty sella supports this theory since the absence of a completely developed pituitary gland may indicate an incomplete migration of Rathke's pouch and adenohypophyseal development. Indeed an empty sella was present in five of the reported cases suggesting that the possibility of an extrapituitary parasellar tumour is higher when an empty sella is found with Cushing's disease.

\section{Adenomas in the neurohypophysis}

Corticotroph adenomas located in the posterior pituitary lobe (neurohypophysis), instead of the adenohypophysis, is also an unusual finding $(6,7)$. Weil et al. recently reported 12 patients with tumours located completely within the neurohypophysis, identified among 730 patients undergoing surgery for Cushing's disease (8). The clinical and biochemical characteristics of these patients were identical to those of ordinary pituitary corticotroph adenomas. However, the sensitivity of MRI scans in detecting these adenomas was extremely low. In general, corticotroph adenomas are small non-enhancing lesions with signal intensity on MRI similar to that of the anterior lobe (9). Since the normal anterior pituitary enhances after the intravenous administration of gadolinium-containing contrast media they are depicted as dark areas. This is not

Table 1. Unusual causes of ACTH-dependent Cushing's syndrome.

\begin{tabular}{l}
\hline Cushing's disease \\
Ectopic corticotroph adenomas \\
Adenomas in the neurohypophysis \\
Double adenomas \\
Non-adenohypophyseal pituitary tumors \\
Gangliocytomas \\
Ectopic CRH Syndrome \\
“Isolated" ectopic CRH syndrome \\
Ectopic ACTH/CRH syndrome \\
Other peptides with CRH-like activity \\
Urocortins (?) \\
Bombesin
\end{tabular}


the case for the adenomas located in the neurohypophysis since neither the intermediate nor the posterior lobe enhance with gadolinium. As for the ectopic corticotroph adenomas, the true incidence of adenomas located within the neurohypophysis may be higher than that estimated from the reported cases. The possibility that they are more common than expected is illustrated by the fact that the same surgeon identified no posterior lobe tumours in the first 460 patients explored for Cushing's disease between 1981 and 1992 , i.e. before the first adenoma confined to the posterior lobe was recognized, but found 12 such tumours in the most recent 270 patients (8).

\section{Double adenomas}

Double adenomas of the pituitary are defined as two morphologically and immunocytochemically distinct tumours (10). Double pituitary adenomas are usually small and therefore only rarely are recognised preoperatively. Positive immunostaining for ACTH in patients with double adenomas is rare and even rarer is the occurrence of clinical hypercortisolism. In 17 out of 21 reported cases prolactinoma was the counterpart of the corticotroph adenoma (11-13) but clinically manifested hyperprolactinemia was evident in only two cases. Interestingly, in three additional reported cases, histology revealed triple adenomas; besides the corticotroph adenoma there were two distinct prolactinomas in one patient (14), and both a sommatotroph adenoma and a prolactinoma in two patients $(12,14)$.

The pathogenesis of double adenomas is unknown but several mechanisms could be considered, including the incidental occurrence of two monoclonal expansions of transformed anterior pituitary cells (multicentric origin). An alternative mechanism is the occurrence of an additional clonal proliferation within an adenoma that was originally of one cell type; in time a new adenoma, as a result of its expansion, may become separate from the old adenoma. The first mechanism is more likely to be the cause of double adenomas composed of ACTH and PRL cells since they originate from two different main pathways of adenohypophyseal cytodifferentiation.

\section{Non-adenohypophyseal pituitary tumours}

Gangliocytomas of the pituitary are a very uncommon cause of pituitary neoplasms with a total of 56 cases reported in the literature. Interestingly, about $65 \%$ are composite lesions with both a gangliocytic and an adenohypophyseal component. In about $75 \%$ of the cases the adenohypophyseal component is functioning, most commonly producing $\mathrm{GH}$ (15). In the vast majority of cases, the hypothalamic releasing hormone of the corresponding hormonal hypersecretion syndrome was immunohistochemically demonstrated in the gangliocytoma portion. There have been only a few cases of Cushing's disease associated with such tumours (16$20)$. In a few cases the gangliocytic component was found to be the only pathology. Geddes et al. (15) reported a patient who was cured by surgical removal of a pure gangliocytoma, suggesting that this lesion was the cause. However, no adenoma or anterior pituitary tissue was found in the resected material. Moreover, they were unable to demonstrate either CRH or AVP mRNA in the tumour and they suggested the hypothesis of paracrine corticotroph stimulation by the lesion.

\section{Ectopic CRH syndrome}

Pituitary hyperfunctioning syndromes caused by hypersecretion of the corresponding hypothalamic hypophysiotropic hormone are extremely rare. Accordingly, the number of well characterized cases of $\mathrm{CRH}$-dependent Cushing's syndrome is distinctively small and comprises of two main groups of patients; those in which concomitant ACTH hypersecretion was documented and who constitute about two thirds of the patients and those in which only an "isolated" $\mathrm{CRH}$ production was found. Wajchenberg et al. reviewed 19 cases of ectopic CRH syndrome (21), and only six had "isolated" CRH production, as opposed to the 13 patients in whom immunostaining was positive for both $\mathrm{CRH}$ and ACTH. Five additional patients with "isolated" $\mathrm{CRH}$ production were subsequently reported (22-26). The most frequently encountered tumours were: metastatic medullary thyroid carcinoma ( 5 cases, one in a woman with MEN IIB syndrome), metastatic prostatic carcinomas (2 cases), metastatic small cell lung carcinomas (2 cases), one metastatic intrasellar gangliocytoma and a pheochromocytoma. Baseline cortisol and ACTH levels in these patients were in the range usually found in patients with "occult" ectopic ACTH syndrome or Cushing's disease. Hormonal evaluation was not reported in detail in all the cases but non-suppression of cortisol levels during high-dose-dexamethasonesuppression testing was reported in all 7 patients who were tested. The levels of serum CRH were frankly elevated in all 4 patients in whom they were measured. The ectopic CRH syndrome as a cause of false-positive result during BIPSS has been underlined by Young et al. (27), who reported a case of a patient with Cushing's syndrome due to ectopic ACTH-CRH secretion from a retropancreatic carcinoid tumour in whom the basal and the stimulated IPS/P ratios were 2.45 and 
4.1, respectively. In this patient also the responses to high-dose dexamethasone suppression and CRH test were consistent with Cushing's disease.

In summary, although CRH-dependent Cushing's syndrome is a distinctively rare syndrome it is important to consider it in the occasional patient with inconsistent results on hormonal tests. Measurement of plasma CRH level, which is now commercially albeit not widely available, is the best method for establishing the diagnosis.

\section{Other peptides}

Apart from $\mathrm{CRH}$, other peptides may also act as ACTH-releasing factors and cause Cushing's syndrome. Peptides such as the urocortins are more potent than $\mathrm{CRH}$ in activating CRH-R2 receptors and bind with greater affinity to $\mathrm{CRH}$-binding proteins. Theoretically oversecretion of these peptides by a tumour could lead to the development of Cushing's syndrome. Although no documented cases have been reported so far, Preeyasombat et al. (28) described a case of Ewings-sarcoma associated with Cushing's syndrome that was negative for ACTH but positive for a corticotropin releasing factor-like peptide, and Aylwin et al. (29) have reported ACTH-dependent Cushing's syndrome and corticotroph hyperplasia caused by a $\mathrm{CRH}$-like peptide secreted by a brain tumour. Moreover, Howlett et al. (30) reported a patient with Cushing's syndrome caused by ectopic production of a bombesin-like peptide from a metastatic medullary carcinoma of the thyroid.

\section{UNUSUAL CAUSES OF ACTH-INDEPENDENT CUSHING'S SYNDROME (table 2)}

\section{Ectopic adrenal adenomas}

The most common cause of ACTH-independent Cushing's syndrome is a hyperfunctioning adrenal tumour, usually a benign adenoma or, less commonly, an adrenal carcinoma. Although in such cases the diagnosis is straightforward with the detection of an adrenal mass in abdominal imaging, a few cases of Cushing's syndrome caused by ectopically located adrenal adenomas have been reported. They are thought to originate from tumoral transformation of ectopic adrenal tissue, known as adrenal rest tissue, which is adrenal tissue located outside the adrenals and is thought to represent adrenocortical embryonic remnants that broke off during development. Adrenal rest tissue is most commonly found in the vicinity of the adrenals but it can also be located anywhere along the embryonic migration path of the adrenals and the gonads, given that both these structures share a common origin, the urogenital ridge. Thus adrenal rests have also been described within the retroperitoneum, broad ligament, ovaries, inguinal region, spermatic cord, kidney, retrocaval space, and testis. A non-ACTH-mediated development of a neoplasm in such tissues is uncommon and the clinical picture depends on the steroid producing profile of the tumour (Conn's syndrome, virilisation or Cushing's syndrome). So far only 9 cases of Cushing's syndrome caused by functional ectopic adrenal neoplasms have been reported (31-38). The ectopic locations involved the vicinity of normal adrenals, the liver, the pararenal region, and the ovary. In four patients the tumours were malignant (31-34). The pathophysiology of ectopic adrenocortical tumorigenesis most probably involves the same mechanisms resulting in eutopic adrenal neoplastic formation. From a clinical standpoint, ectopic adrenal adenomas should be considered in the differential diagnosis of ACTH-independent Cushing's syndrome when the imaging displays normal adrenals. Iodocholesterol scan may be extremely useful in uncovering these lesions.

\section{Bilateral adrenal adenomas}

Bilateral adrenal pathology is encountered in about $10-15 \%$ of patients with ACTH-independent Cushing's syndrome and is due to either ACTH-independent macronodular adrenal hyperplasia (AIMAH) or primary pigmented nodular adrenal disease (PPNAD). Besides these two forms of adrenal Cushing's syndrome, a few cases of functioning bilateral adrenal adenomas have been reported. Less than 30 such cases, the vast majority of the patients being Japanese, can be found in the literature since 1977 and, in all cases, the adenomas were reported to be benign. Nomura et al. (39) reviewed 22 such cases concluding that the clinical and biochemical characteristics of the patients were those of solitary cortisol-producing adenomas. A female predominance was observed $(91 \%)$ and also the size of the adenomas was a little smaller than that reported for solitary adenomas, with a mean size of 2.6

Table 2. Unusual causes of ACTH-independent Cushing's syndrome.
Adrenal Cushing's syndrome
Ectopic adrenal adenomas
Bilateral adrenal adenomas
Altered tissue sensitivity to glucocorticoids
Cortisol hyperreactive syndrome 
$\mathrm{cm}$. Three additional cases were reported hitherto (4042 ); in one patient the two adenomas developed at different periods 9 year apart (42).

The imaging characteristics of bilateral adenomas are quite different from those of PPNAD and AIMAH. In bilateral adenomas there is usually only one single nodule in each gland with surrounding atrophy of the adrenal cortex. However, in one case (43) multiple nodules in each adrenal gland were observed. Typically in AIMAH there is massive enlargement of the adrenals with multiple macronodules measuring up to $5 \mathrm{~cm}$ while in PPNAD the adrenal glands appear normal to slightly hyperplastic with micronodules not exceeding $5 \mathrm{~mm}$. However, larger nodules up to $\mathrm{l}-2$ $\mathrm{cm}$ have been reported in older patients with PPNAD and in these cases the preoperative differential diagnosis from bilateral adenomas is difficult.

On histological examination in each adrenal there is a well-demarcated solitary adenoma which is accompanied by atrophy of the surrounding adrenal tissue. In PPNAD the internodular cortex may also display atrophy but the finding of small multiple pigmented nodules is quite characteristic. In AIMAH the surrounding cortex is usually difficult to identify and may appear hyperplastic although cases with normal or even atrophied tissue have been encountered. However, as has been shown by Nomura et al. (39), the distinction between these pathologies may not always be clear-cut.

Although the definite differential diagnosis of bilateral adrenocortical adenomas from PPNAD and AIMAH is by histological examination, identifying them preoperatively is of great importance because it will affect the surgical approach. Bilateral adrenalectomy necessitating lifelong steroid replacement is the treatment of choice in PPNAD and AIMAH while in bilateral adenomas an effort to preserve the adrenocortical function could be made through bilateral partial adrenalectomy. It is important to document functionality of both adenomas before undergoing bilateral adrenalectomy, since there is also the possibility of the coexistence of a functional and a contralateral nonfunctioning adenoma, as has been reported in a few cases $(43,44)$. In this case adrenal scintigraphy and/or adrenal vein sampling might be of value.

\section{Cortisol hyperreactive syndrome}

The terms "cortisol hyperreactive syndrome", "glucocorticoid hypersensitivity syndrome", and "normocortisolemic Cushing's syndrome" have been used to describe the development of a typical Cushing's phenotype despite normal or even low serum cortisol levels. Although there is a wide variation in glucocorticoid sen- sitivity amongst humans $(45,46)$, clinically manifested Cushing's syndrome due to increased sensitivity of tissues to glucocorticoids is an extremely rare condition and its mechanism remains unclear. To date only 3 patients have been studied to this direction: two with spontaneous Cushing's syndrome and one with exogenous Cushing's syndrome. Iida et al. (47) reported the case of a 54-year-old male with Cushing's syndromelike manifestations but extremely low serum cortisol levels and low 24-hr excretion of 17-hydroxycorticosteroids and cortisol. In order to test the hypothesis that the cause was hypersensitivity of the peripheral tissues to cortisol, they studied the ex vivo effect of dexamethasone on the induction of aromatase activity and thymidine incorporation in cultured skin fibroblasts obtained from the patient. The aromatase activity, which represents a receptor-mediated effect, was increased 1.5- to 1.8 -fold above that of normal cells, and $[3 \mathrm{H}]$ thymidine incorporation was inhibited more effectively (48). Additionally the ex vivo effect of dexamethasone to induce the expression of metallothionein-IIa was studied. The promoter region of this gene which encodes a small metal binding protein contains both a metal regulatory element and a glucocorticoid regulatory element, thus it is a useful gene for studying transcriptional regulation by glucocorticoids. By demonstrating dexamethasone induced increases in the rate of metallothionein-IIa mRNA accumulations in the patient's cells that were greater than those of normal cells, they placed the hypersensitivity at the transcriptional level but the mechanism was not further elucidated (49).

Newfield et al. (50) described another unusual case of a girl who presented at the age of 10 years with most of the classical signs of Cushing's syndrome, such as moon facies, buffalo hump and violaceous striae and also marked osteoporosis with fractures and hyperinsulinemia. She remarkably didn't have easy bruising or stunting of statural growth, which represent two cardinal signs of Cushing's syndrome in childhood. Although her clinical picture was that of Cushing's syndrome, hormonal evaluation revealed normocortisolemia with normal serum cortisol and ACTH levels, normal $24 \mathrm{hr}$ urine free cortisol, suppression of cortisol during low-dose dexamethasone testing and appropriate response to metyrapone test. The circadian rhythm of cortisol was normal in two occasions and abnormal in another two and the response to ovine CRH was blunted. The administration of the glucocorticoid receptor antagonist RU486 resulted in resolution of her symptoms with a prompt recurrence on withdrawal. At the age of 15.5 she discontinued the treatment due to the development of endometrial hyperplasia 
and during the following 2 years the Cushingoid signs gradually disappeared despite an initial rise in GR that persisted for 2 months. The aetiology of the Cushing's syndrome in this case remains a puzzle. Her condition was thought to occur due to differential glucocorticoid sensitivity, rather than generalised, since the nonsuppressed cortisol levels pointed to a normal sensitivity at the hypothalamic-pituitary level but the clinical manifestations to an enhanced sensitivity of the peripheral tissues to glucocorticoids. Ex vivo studies revealed markedly elevated GR sites per cell in peripheral lymphocytes. However, further evaluation demonstrating normal affinity of the GR for dexamethasone, normal primary GR amino acid sequencing and appropriate promoter usage, as well as the transient nature of the Cushingoid features cannot be explained by a genetic defect at the receptor level. A plausible explanation given by the authors is that this case could represent a maturational disorder attributed to a post-receptor defect, possibly due to a mild abnormality in one of the transcription factors, which became evident during a period of deviant fluxes in sex steroids, such as puberty.

In a recent study by Russcher et al. (51), a 13year-old girl was considered to have increased glucocorticoid sensitivity on the grounds of developing Cushingoid phenotype and suppression of the endogenous cortisol production on a low dose of inhaled steroids (budesonide $200 \mu \mathrm{g} /$ day). After stopping the steroid medication her symptoms resolved. Ex vivo analysis showed increased GR number and slightly (but not significantly compared to controls) increasing cellular sensitivity as assessed by measuring responses of endogenous glucocorticoid sensitive genes (leukinezipper and IL-2) and the inhibition of mitogen stimulated proliferation. Defects on the cofactors inducing GR expression or alterations in the promoter region of the GR were speculated as possible causes but the mechanism was not further investigated.

\section{CUSHING'S SYNDROME CAUSED BY MEDICATIONS (table 3)}

Although exogenous hypercortisolism is the commonest form of Cushing's syndrome there are some rare cases in which hypercortisolism was not anticipated either because a small dose of glucocorticoids was administered or because of the route of administration. For example, iatrogenic hypercortisolism due to topical ophthalmic corticosteroid preparations has been reported in three cases, including two children and one adolescent (52-54). As already discussed, increased sensitivity to glucocorticoids could be the underlying mechanism in these unusual cases.

Megestrol acetate, a progestational pharmaceutical compound used in the treatment of advanced breast and endometrial cancer and for the cachexia and wasting associated with HIV infection has also been shown to cause Cushing's syndrome (55). Glucocorticoid-like effects are seen in up to $30 \%$ of patients treated for periods longer than 6 weeks. Although in most cases large doses of the order of $1500 \mathrm{mg} /$ day are usually required for the development of Cushing's syndrome, in few occasions similar clinical features were observed even in patients taking doses of megestrol in the order of $400 \mathrm{mg} /$ day. Raedler et al. (56) studied the effects of megestrol acetate in 10 healthy individuals and noted suppression of ACTH and cortisol levels, suggesting a glucocorticoid-like activity of the compound. Other progestogens, such as medroxyprogesterone acetate, have also been reported to cause clinical hypercortisolism (57).

Exogenous Cushing syndrome in HIV-infected patients receiving ritonavir and fluticasone, even in daily doses of less than $1000 \mu \mathrm{g}$, has been reported frequently (58). Ritonavir, a potent inhibitor of CYP3A4 enzyme, can lead to high systemic concentrations of fluticasone, which is metabolised by CYP34A, when these 2 drugs are co-administered.

\section{CONCLUSIONS}

The differential diagnosis of Cushing's syndrome remains a major clinical challenge. Although in the majority of the patients hypercortisolism is due to ACTH secretion by a pituitary tumour or an extrapituitary neoplastic lesion or to cortisol secretion by an adrenal adenoma, in occasional patients a much rarer entity may be the cause of the syndrome. In order to identify these cases the clinician should be aware of the various unusual forms of Cushing's syndrome. In fact, such unusual presentations of Cushing's syndrome, as those discussed above, represent a demanding diagnostic challenge and illustrate why Cushing's syndrome represents one of the most puzzling endocrine syndromes.

Table 3. Medications that have been unusually associated with Cushing's syndrome.

Topical ophthalmic corticosteroid preparations

Medroxyprogesterone acetate, megestrol acetate

Combination of ritonavir and fluticasone 


\section{REFERENCES}

1. Suzuki J, Otsuka F, Ogura T, Kishida M, Takeda M, Tamiya T, et al. An aberrant ACTH-producing ectopic pituitary adenoma in the sphenoid sinus. Endocr J 2004;51:97-103.

2. Cook DM, Mccarthy PJ. Failure of hypophysectomy to correct pituitary-dependent Cushing's disease in 2 patients. Arch Intern Med 1988;148:2497-500.

3. Ram Z, Nieman LK, Cutler GB, Chrousos GP, Doppman JL, Oldfield EH. Early repeat surgery for persistent Cushing's disease. J Neurosurg 1994;80:37-45.

4. Wahl TO, Kyner JL. Source of ACTH in Cushing's disease. N Engl J Med 1979;300:679.

5. Pluta RM, Nieman L, Doppman JL, Watson JC, Tresser N, Katz DA, et al. Extrapituitary parasellar microadenoma in Cushing's disease. J Clin Endocrinol Metab 1999;84:2912-23.

6. Cushing $\mathrm{H}$. Hyperactivation of the neurohypophysis as the pathological basis of eclampsia and other hypertensive states. Am J Pathol 1934;10:145-U40.

7. Boggan JE, Tyrrell JB, Wilson CB. Trans-sphenoidal microsurgical management of Cushing's disease - Report of 100 cases. J Neurosurg 1983;59:195-200.

8. Weil RJ, Vortmeyer AO, Nieman LK, DeVroom HL, Wanebo J, Oldfield EH. Surgical remission of pituitary adenomas confined to the neurohypophysis in Cushing's disease. J Clin Endocrinol Metab 2006:91:2656-64.

9. Kaskarelis IS, Tsatalou EG, Benakis SV, Malagari K, Komninos I, Vassiliadi D, et al. Bilateral inferior petrosal sinuses sampling in the routine investigation of Cushing's syndrome: A comparison with MRI. AJR Am J Roentgenol 2006; 187:562-70.

10. Kontogeorgos G, Scheithauer BW, Horvath E, Kovacs K, Lloyd RV, Smyth HS, et al. Double adenomas of the pituitary - A clinicopathological study of 11 tumors. Neurosurgery 1992;31:840-9

11. Meij BP, Lopes MB, Vance ML, Thorner MO, Laws ER, Jr. Double pituitary lesions in three patients with Cushing's disease. Pituitary 2000;3:159-68.

12. Ratliff JK, Oldfield EH. Multiple pituitary adenomas in Cushing's disease. J Neurosurg 2000;93:753-61.

13. McKelvie PA, McNeill P. Double pituitary adenomas: a series of three patients. Pathology 2002;34:57-60.

14. Pantelia E, Kontogeorgos G, Piaditis G, Rologis D. Triple pituitary adenoma in Cushing's disease: Case report. Acta Neurochir (Wien) 1998:140:190-3.

15. Geddes JF, Jansen GH, Robinson SFD, Gömöri E, Holton JL, Monson JP, et al. 'Gangliocytomas' of the pituitary - A heterogeneous group of lesions with differing histogenesis. Am J Surg Pathol 2000;24:607-13.

16. Jakumeit HD, Zimmerma V, Guiot G. Intrasellar gangliocytomas. J Neurosurg 1974;40:626-30.

17. Asa SL, Kovacs K, Tindall GT, Barrow DL, Horvath E, Vecsei P. Cushing's disease associated with an intrasellar gangliocytoma producing corticotrophin-releasing factor. Ann Intern Med 1984; 101:789-93.

18. Nishio S, Mizuno J, Barrow DL, Takei Y, Tindall GT. Pituitarytumors composed of adenohypophyseal adenoma and rathkes cleft cyst elements - A clinicopathological study. Neurosurgery 1987;21:371-7.

19. Saeger W, Puchner MJA, Ludecke DK. Combined sellar gangliocytoma and pituitary-adenoma in acromegaly or Cushing's disease - A report of 3 cases. Virchows Arch 1994; 425:93-9.

20. Vidal S, Horvath E, Bonert V, Shahinian HK, Kovacs K. Neural transformation in a pituitary corticotroph adenoma. Acta Neuropathol (Berl) 2002;104:435-40.

21. Wajchenberg BL, Mendonça BB, Liberman B, Pereira MA, Carneiro PC, Wakamatsu A, et al. Ectopic adrenocorticotropic hormone syndrome. Endocr Rev 1994;15:752-87.

22. Auchus RJ, Mastorakos G, Friedman TC, Chrousos GP. Corticotropin-releasing hormone production by a small-cell carcinoma in a patient with ACM-dependent Cushing's syndrome. J Endocrinol Invest 1994;17:447-52.
23. Bayraktar F, Kebapcilar L, Kocdor MA, Asa SL, Yesil S, Canda $\mathrm{S}$, et al. Cushing's syndrome due to ectopic $\mathrm{CRH}$ secretion by adrenal pheochromocytoma accompanied by renal infarction. Exp Clin Endocrinol Diabetes 2006;114:444-7.

24. Oates SK, Roth SI, Molitch ME. Corticotropin-releasing hormone-producing medullary thyroid carcinoma causing Cushing's syndrome: Clinical and pathological findings. Endocr Pathol 2000;11:277-85.

25. Tagliabue M, Pagani A, Palestini N, Manieri C, Martina V. Multiple endocrine neoplasia (MEN IIB) with Cushing's syndrome due to medullary thyroid carcinoma producing corticotropin-releasing hormone. Panminerva Med 1996;38:41-4.

26. Kristiansen MT, Rasmussen LM, Olsen N, Asa SL, Jorgensen JOL. Ectopic ACTH syndrome: Discrepancy between somatostatin receptor status in vivo and ex vivo, and between immunostaining and gene transcription for POMC and $\mathrm{CRH}$. Horm Res 2002;57(5-6):200-4.

27. Young J, Deneux C, Grino M, Oliver C, Chanson P, Schaison G. Pitfall of petrosal sinus sampling in a Cushing's syndrome secondary to ectopic adrenocorticotropin-corticotropin releasing hormone (ACTH-CRH) secretion. J Clin Endocrinol Metab 1998;83:305-8.

28. Preeyasombat C, Sirikulchayanonta V, Mahachokelertwattana P, Sriphrapradang A, Boonpucknavig S. Cushing's syndrome caused by Ewing's sarcoma secreting corticotropin releasing factor-like peptide. Am J Dis Child 1992; 146:1103-5.

29. Aylwin SJB, Geddes JF, Lightman SL. Cushing's syndrome due to an intrasellar gangliocytoma: in vitro and in vivo studies. J Endocrinol 1995;144(suppl):P206.

30. Howlett TA, Price J, Hale AC, Doniach I, Rees LH, Wass JA, et al. Pituitary ACTH dependent Cushing's syndrome due to ectopic production of a bombesin-like peptide by a medullary carcinoma of the thyroid. Clin Endocrinol (Oxf) 1985; 22:91-101.

31. Ney RL, Hammond W, Wright L, Davis WW, Acker J, Bartter FC. Studies in a patient with an ectopic adrenocortical tumor. J Clin Endocrinol Metab 1966;26:299-304.

32. Raith L, Karl HJ. Pregnancy in ectopic adrenal carcinoma. Horm Metab Res 1969;1:149-50.

33. Normann T, Havnen J, Mjolnerod O. Cushing's syndrome in an infant associated with neuroblastoma in two ectopic adrenal glands. J Pediatr Surg 1971;6:169-75.

34. Wallace EZ, Leonidas JR, Stanek AE, Avramides A. Endocrine studies in a patient with functioning adrenal rest tumor of the liver. Am J Med 1981;70:1122-6.

35. Contreras $\mathrm{P}$, Altieri E, Liberman C, Gac A, Rojas A, Ibarra A, et al. Adrenal rest tumor of the liver causing Cushing's syndrome: treatment with ketoconazole preceding an apparent surgical cure. J Clin Endocrinol Metab 1985:60:21-8.

36. Adeyemi SD, Grange AO, Giwa-Osagie OF, Elesha SO. Adrenal rest tumour of the ovary associated with isosexual precocious pseudopuberty and cushingoid features. Eur J Pediatr 1986; $145: 236-8$

37. Leibowitz J, Pertsemlidis D, Gabrilove JL. Recurrent Cushing's syndrome due to recurrent adrenocortical tumor Fragmentation or tumor in ectopic adrenal tissue? J Clin Endocrinol Metab 1998:83:3786-9.

38. Ayala AR, Basaria S, Udelsman R, Westra WH, Wand GS. Corticotropin-independent Cushing's syndrome caused by an ectopic adrenal adenoma. J Clin Endocrinol Metab 2000; 85:2903-6.

39. Nomura K, Saito $H$, Aiba M, lihara M, Obara $T$, Takano K. Cushing's syndrome due to bilateral adrenocortical adenomas with unique histological features. Endocr J 2003; 50:155-62.

40. Desai N, Kapoor A, Singh BK, Liu JX. Bilateral adrenal adenomas and persistent leukocytosis: A unique case of Cushing's syndrome. Am J Med 2006;119.

41. Inoue T, Ishiguro K, Suda T, Ito N, Suzuki $Y$, Taniguchi $Y$, et al. Laparoscopic bilateral partial adrenalectomy for adrenocortical adenomas causing Cushing's syndrome: Report of a case. Surg Today 2006;36:94-7. 
42. Tung SC, Wang PW, Huang TL, Lee WC, Chen WJ. Bilateral adrenocortical adenomas causing ACTH-independent Cushing's syndrome at different periods: A case report and discussion of corticosteroid replacement therapy following bilateral adrenalectomy. J Endocrinol Invest 2004;27:375-9.

43. Kato S, Masunaga R, Kawabe T, Nagasaka A, Miyamoto T, Itoh $\mathrm{M}$, et al. Cushing's syndrome induced by hypersecretion of cortisol from only one of bilateral adrenocortical tumors. Metabolism 1992;41:260-3.

44. Iwase K, Nagasaka A, Tsujimura T, Inagaki A, Nakai A, Masunaga $R$, et al. Cushing's syndrome with cortisol hypersecretion from one of bilateral adrenocortical adenomas Report of a case. Surg Today 1994;24:538-43.

45. Gratsias Y, Moutsatsou P, Chrysanthopoulou G, Tsagarakis S, Thalassinos N, Sekeris CE. Diurnal changes in glucocorticoid sensitivity in human peripheral blood samples. Steroids 2000;65:851-6.

46. Vassiliadi D, Gratsias Y, Tsagarakis S, et al. Glucocortidoid sensitivity assessed in peripheral blood cells do not correlate with the feedback sensitivity of the hypothalamo-pituitary adrenal AXIS. Hormones (Athens) 2002;1:233-8.

47. lida S, Nakamura Y, Fujii H, Nishimura J, Tsugawa M, Gomi $\mathrm{M}$, et al. A patient with hypocortisolism and Cushing's syndrome-like manifestations: cortisol hyperreactive syndrome. J Clin Endocrinol Metab 1990;70:729-37.

48. lida S, Moriwaki K, Fujii H, Gomi M, Tsugawa M, Nakamura $Y$, et al. Quantitative comparison of aromatase induction by dexamethasone in fibroblasts from a patient with familial cortisol resistance and a patient with cortisol hyperreactive syndrome. J Clin Endocrinol Metab 1991;73:192-6.

49. Fujii H, lida S, Gomi M, Tsugawa M, Kitani T, Moriwaki K. Augmented induction by dexamethasone of metallothionein Ila messenger ribonucleic acid in fibroblasts from a patient with cortisol hyperreactive syndrome. J Clin Endocrinol Metab 1993;76:445-9.

50. Newfield RS, Kalaitzoglou G, Licholai T, Chilton D, Ashraf J, Thompson EB, et al. Normocortisolemic Cushing's syndrome initially presenting with increased glucocorticoid receptor numbers. J Clin Endocrinol Metab 2000;85:14-21.
51. Russcher $H$, Smit $P$, van Rossum EF, van den Akker EL, Brinkmann AO, de Heide LJ, et al. Strategies for the characterization of disorders in cortisol sensitivity. J Clin Endocrinol Metab 2006;91:694-701.

52. Ozerdem U, Levi L, Cheng LY, Song MK, Scher C, Freeman WR. Systemic toxicity of topical and periocular corticosteroid therapy in an 11-year-old male with posterior uveitis. Am J Ophthalmol 2000;130:240-1.

53. Romano PE, Traisman HS, Green OC. Fluorinated corticosteroid toxicity in infants. Am J Ophthalmol 1977;84:247-50.

54. Chiang MYM, Sarkar M, Koppens JM, Milles J, Shah P. Exogenous Cushing's syndrome and topical ocular steroids. Eye 2006;20:725-7.

55. Mann M, Koller E, Murgo A, Malozowski S, Bacsanyi J, Leinung M. Glucocorticoidlike activity of megestrol - A summary of Food and Drug Administration experience and a review of the literature. Arch Intern Med 1997;157:1651-6.

56. Raedler TJ, Jahn H, Goedeken B, Gescher DM, Kellner M, Wiedemann K. Acute effects of megestrol on the hypothalamic-pituitary-adrenal axis. Cancer Chemother Pharmacol 2003;52:482-6.

57. Harte C, Henry MT, Murphy KD, Mitchell TH. Progestogens and Cushing's Syndrome. Ir J Med Sci 1995;164:274-5.

58. Arrington-Sanders R, Hutton N, Siberry GK. Ritonavir-fluticasone interaction causing Cushing syndrome in HIV-infected children and adolescents. Pediatr Infect Dis J 2006; 25:1044-8.

Address for correspondence:

Stylianos Tsagarakis

Department of Endocrinology

Athens' Polyclinic

10552 Athens-Greece 